\title{
RECEPTION OF THE SMART CITY CONCEPT IN THE OPINION OF LOCAL ADMINISTRATION OFFICIALS - A CASE STUDY
}

\author{
Katarzyna MIDOR, Aleksandra KUZIOR, Grażyna PŁAZA, Michał MOLENDA \\ Silesian University of Technology
}

Dariusz KRAWCZYK

Department of Social Contacts of the City Hall in Zabrze

\begin{abstract}
:
A city based on the sustainable development priorities, friendly to its residents, combines human activity, technology challenges, and environmental requirements. The implementation of the idea of smart city should be discussed with regard to specific areas of activity. In order to identify the way of perceiving the activity conducted under this concept, a survey was carried out among employees of the City Office in Zabrze. The cognitive, competence and informational scope was verified. It was found that the overwhelming majority of officials (79\%) are convinced that smart city principles are being implemented. The survey participants also provided specific examples of smart-city initiatives undertaken in the city, and a significant part of the respondents (64\%) assigned their professional tasks to them. Moreover, three out of four surveyed officials in Zabrze declared that they know the tools supporting the smart urban development. The results presented in the article constitute pilot studies aimed at understanding the extent to which the Smart City idea is known by local government administration employees. In addition, these results serve as a tool for the authorities of Zabrze to disseminate knowledge about smart city among employees of the city hall.
\end{abstract}

Key words: ISO 37120 standard, Smart City, local government administration, management

\section{INTRODUCTION}

Silesian cities are facing significant ecological, social and economic transformation in the context of the ongoing energy changes that are expected in this region by 2050, in line with the objectives set out in the European Climate Law of 4 March 2020. This involves adapting the commune management to new environmental conditions. Currently, despite many initiatives undertaken by cities, most of them cannot be classified as systematic and orderly. Granting the city a smart label has become fashionable in the political arena, and this concept is often included in various development strategies, while local authorities seem to be substantially unprepared for the implementation of this concept. It is necessary to take measures to improve the quality of life in cities, for example by comprehensive revitalization activities, organizing urban spaces, eliminating urban and architectural chaos, and through real cooperation with city users. A part of the just transition should be activities increasing the quality of life in the region, such as accessibility to health care, participation in culture, public transport, development of schools and universities, housing for rent, senior services, recreational areas. A very important element of the plan is the protection and regeneration of the natural environment, including the improvement of air quality and the revitalization of post-industrial areas. The above-mentioned tasks are of particular importance in Silesian cities being on the verge of economic changes related to the lowemission transformation $[1,2,3]$.

With this in mind, the authors of the article conducted a survey among local administration officials using the example of the city of Zabrze.

Zabrze is located in the centre of the Metropolis GZM (Upper Silesian-Zagłębie Metropolis). As part of the GZM, tasks carried out for organizational and financial reasons are unattainable for individual communes. The activities of the metropolis arise from the Strategic Action Program of the Upper Silesian-Zagłębie Metropolis until 2022 (the so-called PDS) developed in 2018 and are in line with the concept of the Human Smart City implementation. This document is common for the entire metropolitan area and defines development activities for years to come. It is 
a document subject to constant supplements/modifications. At the same time, works on the Development Strategy of the Metropolis GZM for 2022-2027 with a perspective until 2035 are under way.

In accordance with the above-mentioned document, the metropolis has set 5 basic development priorities to be implemented in 2018-2022, i.e.:

1. Shaping spatial order, sustainable "green metropolis", including: development of green areas; rational management of water resources; integrated waste management, including circular economy; optimization of electricity consumption; development of a planning document, the so-called metropolitan study;

2. Development of collective public transport and sustainable urban mobility, and bicycle policy;

3. Social and economic development, including: supporting the implementation of tasks by member communes through subsidies from the Solidarity Fund; creating the so-called Data Store, i.e. an open database concerning various areas of GZM functioning; activities related to the senior policy;

4. Promotion of the metropolitan association and its area, including building a brand and metropolitan identity among residents; cooperation with similar foreign institutions and participation in international events;

5. Institutional development assuming particularly the creation of the Metropolitan Socio-Economic Observatory and a platform for good practices, the development of an internal management system and a joint development strategy for the GZM.

Activities carried out according to these priorities aim to integrate individual potentials of $\mathbf{4 1}$ member communes, initiate development activities and inspire innovative solutions for gradual strengthening of metropolitan functions and improvement of the quality of life in accordance with the smart city idea.

Zabrze was practically a centre of heavy industry until the end of the $20^{\text {th }}$ century. As a coal and steel monoculture, the city faced downright dramatic challenges related to the restructuring of the mining and metallurgy industries. Governments were successively closing mines until they closed the last one owned by the State Treasury in 2016. The systemic shift of the city's character required conceptual work engaging the representatives of all stakeholders of the commune. Therefore, a planning document - "Development Strategy of the City of Zabrze for the years 2008-2020" - came into being, adopted by Resolution No. XXII/284/08 of the City Council in Zabrze of 17 March 2008. The strategy was featured by external and internal political, legal, economic, social, infrastructural and environmental factors influencing the situation of the commune. It also formulated the vision of Zabrze in the adopted time perspective, development priorities, courses of actions and methods of supervision over their implementation. The strategy defined a new vision of the city based on sustainable development, revitalization of degraded areas, and a change of the image. Upon setting far-reaching goals, it was stated that Zabrze will be: "a city building its development by keeping a balance between history and modernity, Silesian identity and metropolitan context as well as housing and investment attractiveness". As part of the development strategy, four priorities have been set: (P1) "Economic environment", (P2) "Modern urban society", (P3) "Attractive public spaces" and (P4) "Metropolitan services". It is worth noting that the previous planning document, the "Strategy for the Development of the City of Zabrze", adopted by Resolution No. XIII/166/99 of the Zabrze City Council on 13 September 1999, set out six directions of development and basic strategic goals: enterprises, (2) Zabrze as a centre of various forms of housing construction and modern construction technologies, (3) shaping a new image of the city, (4) Zabrze as a cultural centre, (5) Zabrze as a medical care centre, and (6) Zabrze as a science centre. After 10 years of implementing the assumptions of the 2008-2020 strategy, Zabrze was already considered a city of medicine, science, sport, tourism, post-industrial heritage, new investments and culture. Therefore, in 2018, the basic planning document was updated.

On 27 August 2018, the City Council adopted the "Development Strategy for the City of Zabrze 2030" establishing four development priorities: "P1. Active urban society" along with the "Actively participate in social development" challenge; "P2. Development and innovation of the economy" with the challenge "To strengthen the economic competitiveness of the city", "P3. The friendliness of the city space" with the challenge" Domestication of space in the city", and "P4. A significant metropolitan position" with the challenge "To stand out in the Upper Silesian-Zagłębie Metropolis". The horizontal objectives corresponding to the specific priorities also include: "Shaping conditions for the development of smart city" $(\mathrm{CH} 2)$.

One of the objectives of our research is to indirectly show that, according to the opinion of public administration, the activities carried out in the city of Zabrze are in line with the idea of a smart city and the assumptions of the GZM strategy, proving that the implementation of the strategy at GZM is consistent with the assumptions of the smart city concept applicable in cities at different latitudes.

\section{LITERATURE ANALYSIS}

Numerical data show that half of the world's population lived in cities, in Europe $73.6 \%$ of the population of the European Union lives in urban areas. 58.2\% of the world and $75.8 \%$ of the European population are expected to live in urban areas by 2025 , and sustainable urbanization has become a key policy point for administrations worldwide [4]. The challenge each city faces is how to best provide the resources and services needed to ensure a thriving population and good economic performance. Smart cities rely on integrated and connected systems to effectively deliver better services and improve citizens' quality of life, ensuring equal opportunities for all and protecting the environment. Cities around the world are currently working on smart city initiatives to make them more effi- 
cient, sustainable, more attractive to citizens and businesses, and to promote economic growth. A smart city is currently a trend in major cities around the world. International standardization bodies have proposed standards for smart cities.

There are many definitions of smart cities, ranging from those that focus solely on infrastructure to those that focus more on empowering citizens and communities to be smarter [5]. No definition fits all cities, and the International Telecommunications Union (ITU, 2015) provides a useful definition: "A smart, sustainable city is an innovative city that uses information and communication technologies (ICT) and other measures to improve quality of life, operational efficiency and urban services and competitiveness, while making sure that it meets the needs of present and future generations in terms of economic, social, environmental and cultural aspects." This definition emphasizes that a smart city is not only a city that uses new technologies; is a complex ecosystem composed of many stakeholders, including citizens, city authorities, local companies and industry, social groups, etc. A smart city is also defined in terms of not only the needs of the present generation, but also the needs of future generations - Smart Sustainable City - which means that the management of the city should take into account the environmental aspect so as not to exceed the local and planetary environmental resources in any way [6]. Identification of the main areas of shaping of the Smart Sustainable City and examples of solutions for environmental protection are issues frequently raised in scientific studies, containing a number of recommendations and practical solutions $[7,8,9]$ and drawing new development trends [10, $11,12,13,14]$. It is more common to see a Smart Sustainable City in the perspective of sustainable solutions with regard to sectors that are crucial for the city's functioning, such as energy $[15,16,17,18,19]$ and water $[20,21,22]$. The actions aim to raise the quality of life of the inhabitants [23, 24]. The ISO 37120 standard has become a tool for measuring sustainable urban development $[25,26$, 27].

The review of the literature concerning the Smart City indicates importance of the matter for contemporary cities aspiring to be modern and friendly to residents. This is a particularly significant issue for cities located in the Silesian agglomeration, especially in the context of just transformation.

\section{RESEARCH METHODS}

In order to identify the way how the Smart City concept is perceived by the employees of the Zabrze City Hall, belonging to the Upper Silesian-Zagłębie Metropolis (GZM), a survey was carried out using a questionnaire in which there are 3 questions concerning initiatives taken as part of the smart city concept. The questionnaire was addressed to all administrative employees of the Office. The study aimed to obtain answer to the question whether the employees of the Zabrze City Hall perform tasks related to Smart City as part of their official duties, and whether, in their opinion, Zabrze, as a city, carries out such activities at all. The respondents were also asked if they knew the tools supporting the development of a smart city. Raising topic like this one is essential because for individual local government units it appears to be necessary to investigate various methods that allow local governments to adapt to the requirements of the contemporary environment. The research was of a pilot nature. The article also draws on an in-depth analysis of the literature devoted to the Smart City concept.

\section{PRESENTATION OF RESEARCH RESULTS}

In the first half of 2021, a survey was conducted among the employees of the Zabrze City Hall. The survey was addressed to all employees. The number of 119 responses were obtained. The questionnaire was anonymous. The purpose of the survey was to collect information on the implementation of the smart city concept in Zabrze by looking at activities carried out by employees of the Office within the framework of their official duties. The questions inquired in the survey are presented in Table 1.

Table 1

Survey questions inquired to the employees of the Zabrze City Hall

1. Does the city at the Office where you work carry out tasks towards a smart city?

$\square$ YES

$\square$ NO

If the answer is YES, please provide examples of such tasks

2. Are there any Smart City matters present in the tasks you perform as part of your duties at the Office?

$\square$ YES

$\square$ NO

If the answer is YES, please provide examples

3. Do you know tools supporting the development of a smart city?

$\square$ YES

$\square$ NO

If the answer is Yes, please provide some examples of such tools

When answering question 1 concerning the implementation of tasks at the City Hall bringing it closer to a Smart City, the commune employees answered "yes" in 79\%, "no" in $1 \%$, and $20 \%$ stated that they had no knowledge on this subject. Figure 1 presents the answers to this question.

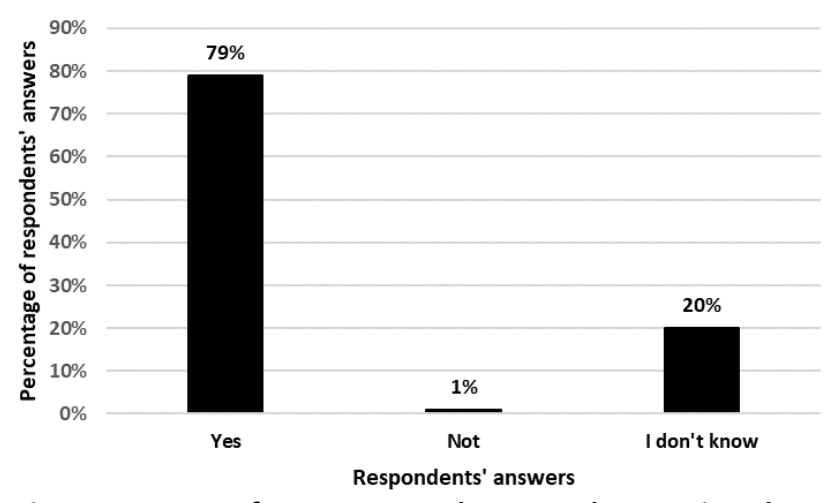

Fig. 1 Responses of commune employees to the question about the implementation of tasks related to a smart city 
The analysis of Figure 1 shows that, according to the employees of the City Hall, in the city being subject to the analysis tasks for the creation of a smart city are carried out. As regards the examples of such tasks, employees replied quite extensively - as shown in Table 2 - listing several initiatives. An interesting phenomenon was the fact is that the respondents who claimed not to know whether activities towards Smart City were implemented in the city or not, also gave examples of such activities conducted by their city; $83 \%$ out of $20 \%$ of such respondents gave a range of examples. It can be concluded that these employees are not entirely convinced that the actions they mentioned can be classified as tasks related to the smart city concept. What can additionally enforce this statement is consideration of the answer provided by about $20 \%$ of respondents who claimed not to know the concept of Smart City.

The analysis of Table 2 shows that activities undertaken in the city concern the basic areas of the functioning of a modern city aspiring to become a smart city. In the group of activities performed as part of the Office organization, one can clearly see the use of various IT systems to improve the office performance and enhance communication with city residents. A number of operations aimed at raising the quality of life of the city's inhabitants, encouraging local entrepreneurship and efforts towards improvement of the broadly understood environment can be also observed. This may prove that the city of Zabrze is well on its way to becoming a Smart City, although, as the employees participating in the survey noted, it is only at the beginning of the road.
Respondents who answered the question 2 regarding the tasks they perform with regard to the Smart City concept, declare that $64 \%$ of them perform such tasks as part of their duties in the office. The remaining part of the respondents, i.e. $35.6 \%$, answered in the negative. This survey question obtained response from 118 employees of the office. The results of the research show that the vast majority of respondents are aware of the fact that the Smart City idea is being fulfilled through their works. The results are shown in Figure 2.

The respondents who admitted performing tasks related to Smart City were asked to provide examples of such tasks. Since the question was open, the respondents gave a number of different examples of such actions. Figure 2 presents a synthetic list of the most frequent examples of the activities.

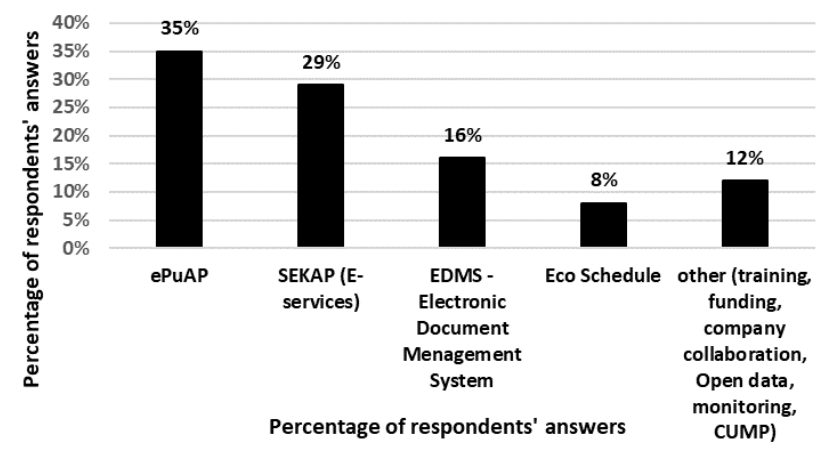

Fig. 2 Examples of employee involvement in Smart City activities

List of examples of the Smart City activities implemented in the City Hall in Zabrze by administrative employees

\begin{tabular}{|c|c|c|c|}
\hline Examples of & f activities performed as part of th & Smart City concep & , divided into areas: \\
\hline $\begin{array}{c}\text { The Office's work } \\
\text { organization }\end{array}$ & Residents convenience & Economy & Envi \\
\hline Electronic document flow & $\begin{array}{l}\text { Public access to information about } \\
\text { the city }\end{array}$ & $\begin{array}{l}\text { Creating business } \\
\text { incubators }\end{array}$ & Security \\
\hline e-services & Efficient communication & $\begin{array}{l}\text { Favourable condi- } \\
\text { tions for investing } \\
\text { in the city }\end{array}$ & Monitoring \\
\hline $\begin{array}{l}\text { Acquisition and settlement of invest- } \\
\text { ments improving the functioning of }\end{array}$ & $\begin{array}{l}\text { Zabrze Broadband Fibre Optic } \\
\text { and Wireless Network }\end{array}$ & $\begin{array}{l}\text { Young Entrepre- } \\
\text { neur Card }\end{array}$ & Clean Air Program \\
\hline
\end{tabular}

the city in various areas (environ-

mental, infrastructural, social)

The strategy of building the infor- Blue Alert App,

mation society

\section{Zabrze in the heart of Silesia}

Eco Harmonogram

City Information Point

Building the Area Information System for the City of Zabrze
Zabrze participatory budget

Installation of boards at bus stops

informing passengers of the bus

departure time

City bike.

Senior 65+ program

Programs

for the improvement of urban space

Family5 +
Development of a Sustainable Energy and Climate Action Plan Development and ongoing updating of the project of supplying the city with heat, electricity and gaseous fuels SioT Information System Transfer Centres 
The largest part of the respondents (35\%) gave an example of the so-called ePUAP, i.e. the Electronic Platform of Public Administration Services on which residents can settle a number of official matters without leaving home. Another example of activity in a position relating - according to $29 \%$ of respondents - to Smart City, was the Electronic communication system of public administration (SEKAP), the platform of public e-services, which, however, will be out of service on 31 December 2021.

Higher in the ranking in terms of the number of indications there were forms of activity such as the Electronic Document Flow (16\%) and the Eco Schedule (8\%) service, which is a mobile application that enable access by the residents to the current waste disposal schedule and to many types of additional information and notifications on the waste.

Since the question is open, the respondents provided a number of other "scattered" examples that were classified and presented in the chart as "other". The most repetitive activities include organization of courses, searching for sources of financing development initiatives, cooperation with entrepreneurs, development of the Open Data project, municipal monitoring service, and support and operation of the Digital City Services for Entrepreneurs (CUMP).

As regards question 3 concerning the knowledge of tools supporting the development of a smart city by employees of the City Hall in Zabrze, 75\% answered that they were familiar with such tools, while $24 \%$ responded negatively. When the answer was "YES", the respondents were asked to name the tools that they know.

The responses varied. However, the above-mentioned tools can be classified into the following categories depending on their level of frequency:

- information and communication tools, including information and communication technologies facilitating work performance in offices, communication with residents; as examples, the respondents gave: electronic document flow, e.g. e-PUAP, text message notifications under the project: Digital City Services for Entrepreneurs (CUMP) and the introduction of the Silesian Public Services Card (ŚKUP), including in particular the mobile passenger application (mobile ŚKUP) on the Android and iOS operating system, e-services, general access for residents to information via the city's website and BIP, a platform for communication between local government units (SEKAP), city applications, screens with key messages for residents, city monitoring, creation of intelligent parking lots enabling to find a parking space, city traffic management system, creating sensors on waste containers to inform about the degree of waste inside, i.e. controlling the amount of municipal waste;

- tools enabling the ecological development of the city, i.e. creating urban spaces, creating bicycle paths, introducing mechanisms to improve air quality, activities supporting energy management, green and blue infrastructure with innovative solutions;
- tools supporting the development of infrastructure including the development of the public transport zone by building new road connections, bicycle paths, investment in the construction of parks, constant improvement of the city's image through the construction of modern and unique facilities such as the Arena Zabrze Stadium or a new transfer centre;

- tools supporting the development of human and social capital, e.g. participation of residents in the development of the city, e.g. creating a participatory budget, promoting sustainable development, acquiring EU and national projects in order to obtain financial resources to pursue the objectives set out in the city development strategy, cooperation with non-governmental organizations;

- cooperation with partner cities, taking advantage of the experience of cities that several decades back were faced with similar problems, e.g. cooperation with Essen.

According to the respondents, a smart city uses information and communication technologies to make key services and elements of urban infrastructure (administration, education, public safety, transport) more useful for the user - improving and facilitating residents' lives, efficient and economically effective.

Despite the lack of an unambiguous definition of a smart city, Giffinger and Haindlmaier (2010) distinguish 6 areas of activities that make up the idea of "smart", i.e.: (1) communication (e.g. well-organized public transport, transport accessibility of the city at the national and international level, provision of ICT infrastructure, sustainable, modern and safe transport systems), (2) management (e.g. participation of residents in decision-making processes, quality of public and social services, transparency of the functioning of authorities, forward-looking development strategy planning), (3) environment (e.g. attractiveness of natural conditions, pollution, emphasis on environmental protection, sustainable resource management), (4) economy (e.g. innovation, entrepreneurship, economic promotion, efficiency, flexible labour market, economic internationalization, ability to change), (5) quality of life (e.g. cultural infrastructure, access to health care, individual safety, housing infrastructure quality, access to education, attractiveness for tourists, social cohesion), (6) people (e.g. level of education, willingness to learn throughout life - lifelong learning, social and ethnic diversity, flexibility, creativity, internationalization, openness to the world, participation in public life).

\section{CONCLUSIONS}

The analysis of the conducted research have shown that, depending on the development priorities adopted in the city, various elements from 6 mentioned areas characterizing a smart city appeared in the answers of the participants. According to the respondents, in the city great importance is attached to the use of information and communication technologies (ICT) in different aspects of their lives, which means that the first area of the smart city con- 
cept is being fulfilled. It should be noted that the respondents also named tools useful in developing other areas of the smart city concept.

A modern city is a complex ecosystem composed of several elements that connect people, the environment and technology. In such an ecosystem, it is important to integrate the infrastructure by introducing the so-called Internet of Things (IOT) that will boost efficiency and join activities of the entire ecosystem. The research showed that various services (metering water consumption, energysaving LED lighting with a management system, city bike systems, air quality monitoring, parking space management, waste collection and disposal, administration management and electricity supply) operate through the Internet. For the time being, individual activities are interconnected to a minimal degree, but in the future the city pursue introducing a communal integrated Smart loT system. Establishment of the integrated loT system for many areas is what the future holds for Polish cities, enabling their effective management.

In the last century, urban infrastructure was understood primarily in the context of urban infrastructure itself (communication, parking, energy), while nowadays the intelligence of a city is defined in a broader spectrum that encompass the economic, environmental, social and educational dimensions. This is what the ISO 37120 standard, known as the smart city standard, says. The standard defines and identifies a total of 100 indicators whose meeting at a certain level allow the city to be recognized as 'smart.'

In Poland, the cities that have already been verified are Gdynia, Gdansk, Kielce and Lublin. Providing information online makes it possible to measure what is already in the city, obtain certification and help improve the quality of life of the inhabitants.

\section{REFERENCES}

[1] Giffinger R., Haindlmaier G. Smart cities ranking: An effective instrument for the positioning of cities? ACE: Architecture, City and Environment. IV (12), 2010. pp. 7-25.

[2] Midor, K., Płaza, G., Molenda M. PN-ISO 37120 standard known or unknown by local administration - preliminary study, in: Multidisciplinary aspects of production engineering. Monograph. Pt. 2, Social sciences. Ed. Patrycja Hąbek, Warszawa, 2021. Sciendo.

[3] Midor, K., Płaza, G. Norma ISO 37120 - nowe narzędzie do oceny i porównania inteligentnych miast, in: Inteligentny rozwój inteligentnych miast. Ed. Izabela Jonek-Kowalska, Jan Kaźmierczak, Warszawa, CeDeWu, 2020. pp. 189-202

[4] Colldahl, C., Frey, S. and Kelemen, J.E. Smart Cities: Strategic Sustainable Development for an Urban World. Master's Thesis, Blekinge Institute of Technology, Karlskrona, Sweden. 2013.

[5] Albino, V., Berardi, U. and Dangelico, R.M. Smart cities: Definitions, dimensions, performance, and initiatives. Journal of Urban Technology, 22(1), 2015. pp. 3-21.
[6] Höjer, M., Wangel, J. Smart Sustainable Cities: Definition and Challenges [in:] Hilty, L.M., Aebischer, B. (eds.). ICT Innovations for Sustainability, Advances in Intelligent Systems and Computing 310, Springer International Publishing, Zurich, 2014. pp. 333-350.

[7] Hancke, G.P., Salehizadeh, M.R., Liu, X., Hu, J., Abu-Mahfouz, A.M., Thomos, N., Ishihara, S., Savaglio, C. Guest editorial: loT sensing, applications, and technologies for smart sustainable cities, IET Smart Cities 3(3), 2021. pp. $121-124$

[8] Lakhno, V., Malyukov, V., Bochulia, T., Hipters, Z., Kwilinski, A., Tomashevska, O. Model of Managing of the Procedure of Mutual Financial Investing in Information Technologies and Smart City Systems. International Journal of Civil Engineering and Technology 9 (8), 2018. pp. 1802-1812

[9] Kuzior, A. Polish and German Experiences in Planning and Implementation of Sustainable Development. Problemy Ekorozwoju - Problems of Sustainable Development, 5(1), 2010. pp. 81-89.

[10] Alagirisamy, B., Ramesh, P. Smart Sustainable Cities: Principles and Future Trends. Lecture Notes in Civil Engineering 183, 2022. pp. 301-316

[11] Bibri, S.E. The underlying components of data-driven smart sustainable cities of the future: a case study approach to an applied theoretical framework. European Journal of Futures Research 9(1),13. 2021.

[12] Pira, M. A novel taxonomy of smart sustainable city indicators. Humanities and Social Sciences Communications, 8(1), 197. 2021.

[13] Mikhnevych, L., Marchenko, V., Hristov, P., Kuzior, A. Conceptual relationships between country image and economic security, Marketing and Management of Innovations, no. 1, 2020. pp. 285-293.

[14] Kuzior, A., Kuzior, P. The quadruple helix model as a smart city design principle. Virtual Economics 3 (1), 2020. pp. 3957.

[15] Anjali, S.K., Aki, S., Kenji, I. Tokyo Smart Global Megacity Smart Sustainable Energy Solutions. Advances in $21^{\text {st }}$ Century Human Settlements, 2022. pp. 191-218

[16] Thornbush, M., Golubchikov, O. Smart energy cities: The evolution of the city-energy-sustainability nexus. Environmental Development 39, 100626. 2021.

[17] Vakulenko, I., Saher, L., Lyulyov, O., Pimonenko, T. A systematic literature review of smart grids. E3S Web of Conferences, 250, 08006. 2021.

[18] Kuzior, A., Lobanova, A., Kalashnikova, L. Green Energy in Ukraine: State, Public Demands, and Trends. Energies 2021, 14, 7745.

[19] Grebski, W., Grebski, M.E. Building an Ecosystem for a New Engineering Program Management Systems in Production Engineering, 26(2), 2018. pp. 119-123.

[20] Ramos, H.M., McNabola, A., López-Jiménez, P.A., PérezSánchez, M. Smart Water Management towards Future Water Sustainable Networks. Water, 12, 58. 2020.

[21] Howell, S., Beach, T., Rezgui, Y. Robust requirements gathering for ontologies in smart water systems. Requirements Engineering 26(1), 2021. pp. 97-114.

[22] Kuzior, A., Ober, J., Karwot, J. Stakeholder Expectation of Corporate Social Responsibility Practices: A Case Study of PWiK Rybnik, Poland. Energies 2021. 14 (11), 3337. 
[23] Radziejowska, A., Sobotka, B. Analysis of the Social Aspect of Smart Cities Development for the Example of Smart Sustainable Buildings. Energies 2021. 14 (14), 4330.

[24] Moschen, S.A., Macke, J., Bebber, S., Benetti, M. Sustainable development of communities: ISO 37120 and UN goals. Correa da Silva International Journal of Sustainability in Higher Education, 20, 5, 2019. pp. 887-900.

[25] Legutko-Kobus, P. E-partycypacja i ISO 37120 jako wyznacznik implementacji rozwoju zrównoważonego w smart city. Studia Ecologiae et Bioethicae, 1, 2021. pp. 7182.

\section{Katarzyna Midor}

ORCID ID: 0000-0001-5680-7354

Silesian University of Technology

Faculty of Organization and Management

ul. Roosevelta 26-28, 41-800 Zabrze, Poland

e-mail: katarzyna.midor@polsı.pl

\section{Aleksandra Kuzior}

ORCID ID: 0000-0001-9764-5320

Silesian University of Technology

Faculty of Organization and Management ul. Roosevelta 26-28, 41-800 Zabrze, Poland

e-mail: aleksandra.kuzior@polsı.pl

\section{Grażyna Płaza}

ORCID ID: 0000-0001-5862-0905

Silesian University of Technology

Faculty of Organization and Management

ul. Roosevelta 26-28, 41-800 Zabrze, Poland

e-mail: grażyna.plaza@polsl.pl

\section{Michał Molenda}

ORCID ID: 0000-0002-0276-742X

Silesian University of Technology

Faculty of Organization and Management

ul. Roosevelta 26-28, 41-800 Zabrze, Poland

e-mail: michal.molenda@polsl.pl

\section{Dariusz Krawczyk}

ORCID ID: 0000-0003-1823-0309

Department of Social Contacts of the City Hall in Zabrze ul. Powstańców Śląskich 5-7, 41-800 Zabrze, Poland
[26] Balova, S.L., de Velazco, J.J.H.G., Polozhentseva, I.V., Chernavsky, M.Y., Shubtsova, L.V. The formation of the concept of smart sustainable city with the purpose of environmental protection Journal of Environmental Management and Tourism 12(5), 2021. pp. 1269-1275.

[27] Panagiotakopoulos, T., Vlachos, D.P., Bakalakos, T.V., Kanavos, A., Kameas, A. A FIWARE-based IoT Framework for Smart Water Distribution Management. IISA 2021. $12^{\text {th }}$ International Conference on Information, Intelligence, Systems and Applications, 9555509 